\title{
Şirket Değerlemesine Kuramsal Açıdan Genel Bir Bakış
}

\author{
Mustafa GÖZEN \\ Enerji Piyasası Düzenleme Kurumu, Ankara \\ mgozen@gmail.com \\ ORCID ID: https://orcid.org/0000-0002-5195-757X
}

\begin{tabular}{lr} 
Araştırma Makalesi & DOI: 10.31592/aeusbed.573125 \\
\hline GelişTarihi: 31.05.2019 & Kevize Tarihi: 11.11.2019 Tarihi: 13.11 .2019 \\
Atıf Bilgisi & \\
Gözen, M. (2019). Şirket değerlemesine kuramsal açıdan genel bir bakış. Ahi Evran Üniversitesi Sosyal Bilimler \\
Enstitüsü Dergisi, 5(2), 198-219.
\end{tabular}

ÖZ

Şirket değerlemesi finans yazınında 1980'li yıllardan itibaren gündeme gelen bir konu olmuştur. Günümüzde sermayenin serbest dolaşımı, varlık veya hisse senedi alım ve satımı, şirket bölünme ve birleşmeleri değerleme işini gündeme getirmektedir. Bunun yanında, rekabet ortamında şirket değerinin artırılmasına ilişskin alternatiflerin belirlenmesi ve şirket değerinin stratejik yönetimi de önem kazanmıştır. Bu doğrultuda, finans disiplini konuya şirket hissedarları bakımından şirket değerinin tespiti ve şirket değerinin yönetilmesi olarak bakmaktadır. Literatürde birçok değer türünden ve değerleme yönteminden bahsedilmektedir. Şirket değerlemesinde kullanılacak yöntemin belirlenmesinde, değerlemede güdülen amacın ve ilgili şirketin yapısı ve içinde bulunduğu durumun dikkate alınması gerekmektedir. Şirket değerlemesinde kullanılan yöntemler teorik açıdan güçlü olup uygulamada karşılaşılan temel problem her yöntemin gerektirdiği girdi parametrelerinin uygun bir şekilde belirlenmesidir. İncelenen şirket değerleme yöntemlerinde, yöntem için gerekli tüm girdilerin değerinin bilindiği varsayılmıştır. Günümüzde şirketler çok sayıda değişkenin etkileşim halinde olduğu bir ortamda faaliyette bulunmaktadırlar. Bu nedenle, belirsizliğin yüksek olduğu bir ortamda söz konusu girdilerin değerinin belirlenmesi kolay olmayacaktır. Bu tür ortamda, şirket değerlemesinde belirsizliği dikkate alan analizler kullanılabilir.Bu şekilde, şirket değerine ilişkin bir değerler kümesi elde edilebilir ve şirket ile ilgilenen taraflara verecekleri karara baz oluşturacak bilgi sağlanmış olur. Ancak buanalizler ile hesaplanacak şirket değerinin şirket ile ilgili taraflara belirsizlik altında bir fikir vereceği dikkate alınmalıdır.

Anahtar Kelimeler: Değer, değerleme, değerleme yöntemleri, şirket değerleme.

\section{An Overview of Corporate Valuation from the Theoretical Perspective}

\begin{abstract}
Corporate valuation has been an issue in the finance literature since the 1980s. Today, the free movement of capital, the purchase and sale of assets or shares, the divisions and mergers of companies have brought thevaluation work to the agenda. In addition, the determination of alternatives for increasing the value of a company in a competitive environment and the strategic management of corporate value have gained importance. In this respect, the discipline of finance considers the issue as the determination of corporate value from the perspective of company shareholders and the management of corporate value.Many types of values and valuation methods are mentioned in the literature. In determining the method to be used in the corporate valuation, the purpose of the valuation and the structure and situation of the relevant company should be taken into consideration. The methods used in corporate valuation are theoretically strong and the main problem encountered in practice is the proper determination of the input parameters required by each method. In the corporate valuation methods examined, it is assumed that the value of all inputs required for the method are known. Today, companies operate in an environment where many variables interact. Therefore, in an uncertain environment, it will not be easy to determine the value of these inputs. In such an environment, analyzes that consider uncertainty in corporate valuation may be used. In this way, a set of values can be obtained for the corporate value and information is provided to the stakeholdersas a basis for their decision. However, it should be taken into consideration that the corporate value to be calculated with these analyzes will give stakeholders an idea under uncertainty.
\end{abstract}

Keywords:Value, valuation, valuation methods, corporate valuation. 


\section{Giriş}

İşletmelerde şirket değerlemesi, 1980 yılı başından itibaren artan bir şekilde uygulanmaya başlamıştır. Günümüzde küreselleşen ekonomik ortamda, yatırımcılar sermayelerini en fazla getiriyi sağlayacak şekilde bir yerden başka bir yere kolay ve hızlı bir şekilde transfer edebilmektedirler. Bu çerçevede, şirketlerdeki hisse senedi satımı ile şirket bölünme ve birleşmelerinde değerleme işi gündeme gelmektedir (Ercan, Öztürk ve Demirgüneş, 2003). Rekabetin giderek arttığ 1 ortamda, şirket yönetiminin şirket değerini maksimum kılması ve bu amaçla uygun yönetim yaklaşımı geliştirmesi kaçınılmaz görülmektedir. Günümüzde şirketlere değer biçilmesinin yanında, şirket değerinin artırılması yollarının tespiti ve şirket değerinin stratejik yönetimi de önem kazanmakta ve benimsenmektedir (Ercan vd., 2003). Finans disiplini değerleme kavramını zaman boyutunda bugün yerine gelecek açısından ele almaktadır. Hatta finans disiplini konuya şirket hissedarları bakımından şirket değerinin tespiti ve şirket değerinin yönetilmesi olarak bakmaktadır (Ercan ve Ban, 2005). Bu bakış açısından, şirketin amacının şirket değerinin hissedarlar açısından maksimum kılınması olduğu söylenmektedir. Finans disiplinine göre bir şirketin değerlemesi, söz konusu şirketin ya varlıklar bazında ya da geliri bazında değerlemesidir (Bilir ve Kulalı, 2014; Cesur, Tekindağ ve Ergün, 1999). Ancak şirket değerleme işinde genel kabul gören, tek bir hesaplama yöntemi bulunmamaktadır. Birden fazla yöntem ile bulunan sonuçlar karşılaştırma yapmak için kullanılmaktadır. Bu bakımdan, farklı yöntemler ile elde edilen değerleme sonuçları ile şirket değeri hakkında bir fikir edinilebilir.

$\mathrm{Bu}$ çalışmanın amacı, şirket değerlemesinin kuramsal açıdan genel bir bakış açısı ile incelenmesidir.Bu amaç doğrultusunda; ikinci bölümde değerin öznel ve nesnel boyutları incelenmiş, üçüncü bölümde değer türlerine değinilmiş, dördüncü bölümde şirket değerlemesinin nedenleri ve stratejik önemi tartışılmış, beşinci bölümde değerleme yaklaşımları ve şirket değerleme yöntemleri açıklanmış, altıncı bölümde ele alınan konu hakkında değerlendirme yapılmış ve konu farklı boyutlarıyla tartışılmıştır. Yedinci ve son bölümde varılan sonuçlara yer verilmiştir.

\section{Değerin Boyutları}

Değerlemede değerlemeye konu şey ve değerlemeyi kimin yapacağ önemli olmaktadır. Bu özellik, değerin öznel ve nesnel olmak üzere iki boyutuna işaret etmektedir. Öznel değer, birey ve taleplerine bağlı olarak şekillenen değeri, nesnel değer ise mal ve hizmetlerin maliyet ve faydaları ile orantılı olarak belirlenen değeri ifade etkmektedir (Cesur, 1993). Değer birçok faktörün etkisi altında oluşmaktadır. Buradan hareketle, toplam değer ve bileşenleri Şekill'de verilmiştir.

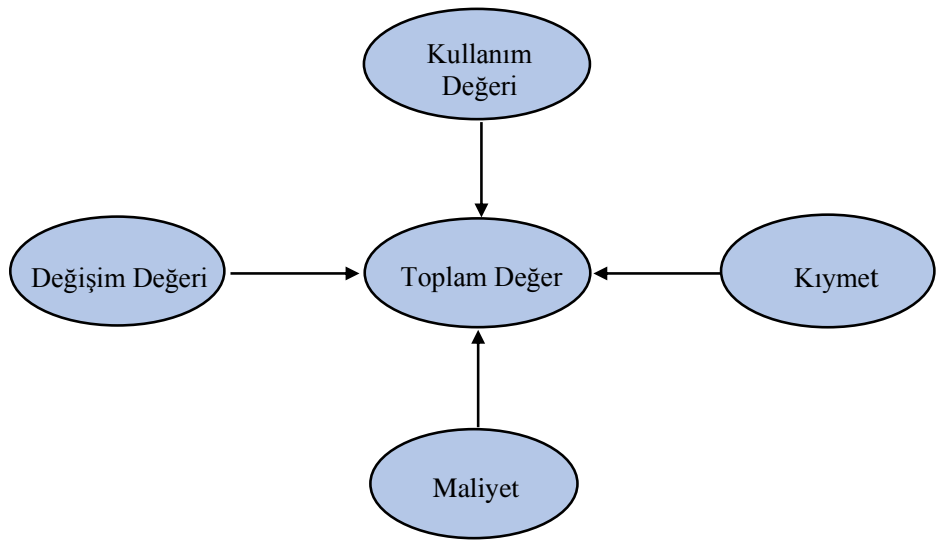

Şekil 1. Toplam Değer ve Bileşenleri

Değer kavramının iki boyutu bulunmaktadır: Kullanım değeri ve değişim değeri (Yazıcı, 1997). Kullanım değeri bir malın yararlılığına karşılık gelmektedir. Değişim değeri ise bir malın başka bir malı satın alma gücünün bir ölçüsü olmaktadır. Buna göre; herhangi bir nesnenin sağladığı toplam fayda kullanım değerine, herhangi bir nesnenin başka birine verildiğinde karşılığında alınabilecek nesne miktarı ise değişim değerine karşılık gelmektedir. Değişim değerinde karşılık olarak alınan şey 
para ise verilen nesnenin fiyatı, o nesnenin değeri olmaktadır. Aksi belirtilmedikçe, değer kelimesinden genellikle değişim değeri anlaşılmaktadır.

\section{Değerin Öznel Boyutu}

Değerin öznel boyutuna göre değer, birey ve isteklerine göre belirlenmektedir. Bu bakış açısına göre, malların objektif ve ölçülebilir değerleri yoktur. Herhangi bir varlık; cazibesi, kalitesi, biçimi, ağırlığı veya rengine göre değerlendirilebilir ve bu değer zaman içinde değişen bir özelliğe sahiptir (Yazıcı, 1997). Bu nedenle, değer bireylerin mallarda buldukları tatmine ve bakış açısına göre değişen göreceli bir kavram olmaktadır. Dolayısıyla, aynı mala atfedilen değer bireylere göre değişen bir kavram olmaktadır (Kuçuradi, 1998). Bununla beraber, öznel değer anlayışında faydanın ölçülebilir olduğu varsayılmıştır. Şirkete ilgisi olan gruplar dâhilolmak üzere, değerlemeyi kimin yaptığı değeri doğrudan etkileyen bir unsur olmaktadır. Şirket ile yakın ilişki içinde olan şirket hissedar ve yöneticileri şirket hakkında ayrıntılı bilgiye sahip olmaktadırlar. Dolayısıyla, şirket hissedar ve yöneticileri şirketin geleceğini, geleceğe yönelik politika ve stratejilerini kendileri belirledikleri için şirkete biçecekleri değer, şirket dışı gruplara göre farklı ve gerçeğe daha yakın olması beklenir.

Her türlü değerlemede; bakış açısı belirleyici olmaktadır. Bir şirketin başka bir şirket açısından değeri, söz konusu şirketin bakış açısına göre farklı olabilmektedir. Objektif ölçütlere dayalı bir değer ölçümü yoktur ve farklı bakış açılarından farklı değerlere ulaşılabilir (Kuçuradi, 1998). Bu çerçevede, şirket değeri ile şirket hissedarlarının elindeki hisse senetlerinin değerini de birbirinden ayırmak gerekmektedir. Şirket hissedarları açısından önem arzedenhisse senedi değeri, şirket değeri ile üst üste örtüssen değer olarak aynı anlamda ele alınmamalıdır (Ward ve Grundy, 1996). Şekil 2'de ayrıntılı olarak gösterildiği üzere;bir şirketin dış dünya açısından, başka bir anlatımla mevcut hissedarları ve/veya potansiyel hissedarları açısından değeri, şirket yönetimi açısından biçilecek şirket değerinden farklıdır (Donaldson ve Preston, 1995). Şirket yönetimi, şirketin hissedarlarına göre daha fazla miktarda ve sağlıklı bilgiye sahiptir. Bu nedenle, şirket yönetiminin biçeceği şirket değeri daha gerçekçi bir değer olacaktır.

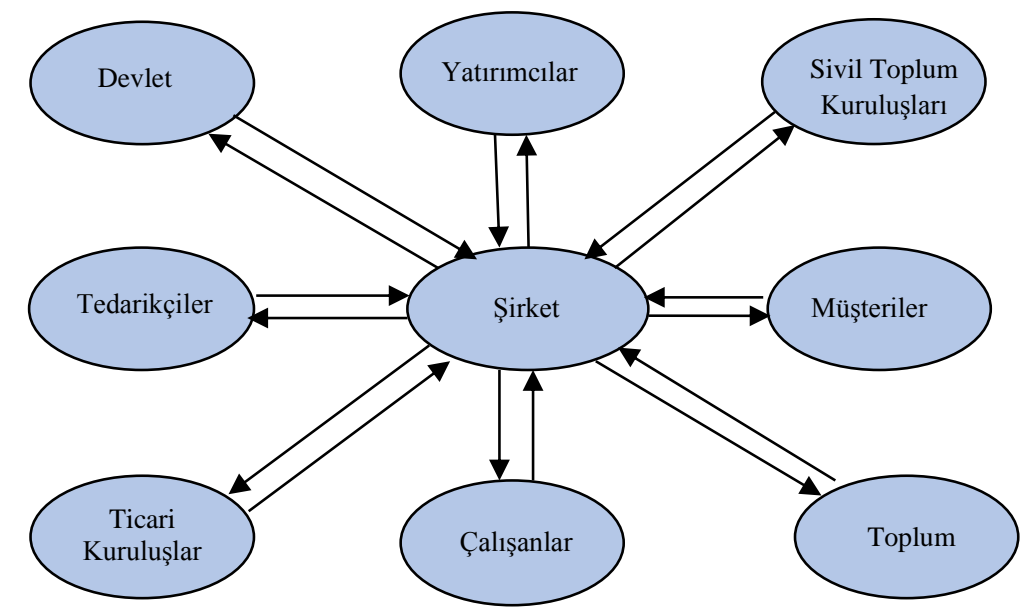

Şekil 2. Şirket ile Dış Çevresi Arasındaki Farklı Çıkar Grupları Modeli (Kaynak: Donaldson, T. and Preston, L. E. (1995). The stakeholder theory of the corporation: Concepts, evidence, and implications.Academy of Management Review, 20(1), 69-70).

Hisse senedi değeri, şirket yönetiminin sermaye piyasasının beklediği karlılı̆g 1 tutturmaya yöneliktir. Bu değer türü, şirketin hâlihazırda sermaye piyasasındaki değeri olup mevcut hissedar ve potansiyel yatırımcılara bağlı bir değerdir. Şirket değeri, şirket yönetiminin bilgisi dâhilindeki şirketin strateji ve geleceğe yönelik yatırım programı bilgilerinin bir fonksiyonu olmaktadır (Donaldson ve Preston, 1995). Şirket yönetimi bu değerin şirketin piyasa değerine yansımasına çaba gösterir. Şirket dışı yatırımcılar, potansiyel yatırımcılar, devlet, işçi sendikaları gibi çıkar grupları şirket ile ilgili olarak sadece bilanço, gelir tablosu ve nakit akımı tablosu gibi temel finansal tablolara 
ulaşabilmektedir. $\mathrm{Bu}$ finansal tablolara dayalı olarak yapacakları değerleme bu tablolardaki bilgi ile sınırlı olmaktadır. Şirket içi ve dışı çevre, şirket hakkında aynı miktar ve kalitede bilgiye sahip olmadığından aynı değere ulaşmaları beklenemez. Bu nedenle; şirket hissedarları, şirket yönetimi, kredi verenler ve şirket çalışanları açısından farklı şirket değerlerine ulaşılır.

\section{Değerin Nesnel Boyutu}

Bir mala biçilen değer, her zaman aynı olmayıp içinde bulunulan zaman ve duruma, hatta bakış açısına göre değişmektedir (Akarsu, 1998; Bolay, 1996; Cevizci, 1999; Mülayim, 1994). Değerin bu niteliğinin,hem değer biçen hem de yapılmıș olan değer biçme sonucunu inceleyen kiși tarafından dikkate alınması gerekmektedir (Mülayim, 1994). Diğer taraftan, Mülayim (1994)'e göre değer biçmenin amacı bilinmeden bir mala veya varlığa değer biçilmesimümkün değildir ve değerleme sonuçları, o değer biçmede güdülen amaç bilinmeden doğru olarak yorumlanamaz.Bu bakımdan değer biçmenin amacının bilinmesi gereklilik arzetmektedir.Amaçtaki farklılaşmaya bağlı olarak farklı değer kümesine ulaş1lır. Bu şekilde hesaplanacak değerlerin her birini doğru olarak kabul etmek gerekir. Zira amaca bağlı olarak her bir değerlemede farklı varsayım ve ekonomik boyut ele alınmıştır.Şirketin içinde bulunduğu durum değerlemede belirleyici olmaktadır. Şirketin tasfiye veya dağılma halinde olması ile yüksek büyüme hızına veya pazar payına sahip olduğu durumlarda uygulanacak değerleme yöntemi de aynı olmayacaktır (Cornell, 1993). Faaliyeti sona erdirilmesi veya varlıkları satılması düşünülen bir şirket ile aynı şirketin varlıkları ile birlikte üçüncü bir kişiye devredilmesi durumunda farklı değerleme yöntemleri kullanılacaktır. Cornell (1993)'e göre şirketin yapısı, değerlemede kullanılacak en uygun yöntemin seçiminde belirleyici faktörlerden biri olmaktadır. Üretim, toptancılık, perakendecilik, dağıtım gibi faaliyet ile iştigal eden şirketlerin gerek varlık gerekse geliri birlikte ele alan yöntemler ile değerlemesi yapılmalıdır (Yazıcı, 1997). Bu tür şirketler ile ilgilenen potansiyel yatırımcılar hem varlıklar hem de şirketin gelir yaratma gücü ile ilgilenebilir. Değerlemeye konu şirket hizmet sektöründe faaliyette bulunuyorsa, şirketin varlıktan ziyade gelir yaratma gücünü dikkate alan yöntemler ile değerlemesi yapılmalıdır.

Şirket değerlemesinin amac1; şirketin uygun ve makul piyasa değerinin belirlenmesidir(Yazıcı, 1997).Bu nitelikte bir piyasa değeri ise, piyasada varlıkların değeri konusunda tam bilgiye sahip istekli alıcı ve satıcıların herhangi bir zorlama olmadan, söz konusu varlık için piyasada takdir ettikleri alım ve satım değerine karşılık gelir (Cornell, 1993; Yazıcı, 1997; Ertuğrul, 2008). Güdülen amaca göre şirket değerlemesi üç ana başlık altında toplanabilir. Bunlar; şirket faaliyetlerinin değerlemesi, şirketin önündeki firsatların değerlemesi ve şirket sahipleri açısından değerlemedir(Cornell, 1993). Söz konusu değerlemeye ilişkin açıklamalar aşağıda verilmiştir.

- Şirket faaliyetlerinin değerlemesi:I̧şletmelerde en temel ve yaygın değerleme şekli, şirket faaliyet veya varlıklarının yerinde değerlemesidir. Şirketlerin çeşitli nedenlerle tamamı veya bir kısmının değerlemesine ihtiyaç duyulabilir. Bu tür değerleme için nakit akımı yöntemi amaca hizmet eden bir yöntem olmaktadır (Piper ve Fruhan, 1981).

- Şirketin önündeki firsatların değerlemesi: Şirketlerin gelecekte tercih etmek durumunda kalabileceği seçeneklerin değerlemesi de ayrı bir değerleme işi olmaktadır. Bu tür değerlemede opsiyon fiyatlandırma teorisinin kullanılması uygun olmaktadır.

- Şirketin hissedarları açısından değerlemesi: Bir şirketin ortak girişim şirketi olması veya bir projenin stratejik işbirliği ve/veya proje finansmanı ile çok ortaklı olarak gerçekleştirilmesi durumunda, şirket ortaklığ 1 bir veya birden fazla gerçek kişi ve/veya tüzel kişi arasında paylaşılmaktadır. Bu tür şirketlerde, şirket ortakları şirketin toplam değerini veya kendi paylarına düşen şirket değerini bilmek isteyebilir. Şirkete yeni ortak alınması veya ortaklardan birinin ayrılması durumunda, şirketin hisse değerinin hesaplanması ihtiyacı ortaya çıkabilir. Bu amaçla; fiyat/kazanç oranı, piyasa değeri/defter değeri oranı veya temettü esasına dayalı yöntem ile şirketin hisse senetlerinin değeri hesaplanabilir. 


\section{Değer Türleri}

Değerin genel kabul görecek bir tanımının yapılmasının zor olduğu anlaşılmaktadır. Ancak uygulamada ticari ve vergi gibi çeşitli amaçlar için geliştirilmiş farklı değer türleri kullanılmaktadır. Literatürde ve Türkiye'de birincil mevzuatta geçen ve kullanımı olan değer türlerine örnek olarak; defter değeri, piyasa değeri, tasfiye değeri, yeniden yapma değeri, işleyen teşebbüs değeri, emsal değeri, ekspertiz değeri, net aktif değeri ve piyasa kapitalizasyondeğerleri verilebilir (Alkan ve Demireli, 2007; Mevzuat Bilgi Sistemi, 1994). Bu değer türleri aşağıda kısaca açıklanmıştır.

\section{Defter Değeri}

Defter değeri; teorik olarak, belirli bir tarihte tarihi değerle kayıtlı varlıkların muhasebe kayıtlarına göre belirlenmiş değeri olmaktadır (Ercan vd., 2003; Gönenli, 1991). Başka bir deyişle; defter değeri, şirketin toplam varlıkları ile toplam yükümlülükleri arasındaki farkı ifade etmektedir (Öztürk, 2009). Muhasebe tekniklerindeki farklılık sonucu varlıkların defter değerleri de farkl1 olabilmektedir. Örneğin; kur farkları aktifleştirilerek yatırımlara dâhil edilebileceği gibi, giderleştirilerek gelir tablolarına da yansıtılabilir. Bu durumda varlıkların defter değeri farklı olacaktır. Aynı şekilde, farklı amortisman yöntemi ve stok değerleme yönteminin uygulanması sonucunda farklı defter değerlerine ulaşılır.Bu değer türünde şirketin gelir yaratma gücü dikkate alınmamaktadır. $\mathrm{Bu}$ bakımdan, geleceğe yönelik gelir yaratma potansiyeli yüksek şirketler için defter değerinin uygulanması doğru olmayacaktır. Bu tespit, bu değer türünün zayıf yönüne karşılık gelmektedir.

\section{Piyasa Değeri}

Piyasa değeri, piyasa koşullarında arz ve talebe göre oluşan bir değer türüdür (Gacar, 2009). Başka bir deyişle bu değer, değerleme açısından yeterli derecede bilgiye sahip olarak, satma veya satın alma baskısı altında olmadan, herhangi bir malı talep eden bir satıcının satacağı, talep eden bir alıcının satın alacağı değere karşılık gelmektedir. Bu değer türü, sadece etkin işleyen bir piyasa ve varlıkların el değiştirmesinin kolay olduğu ortamda önem kazanmaktadır.

\section{Tasfiye Değeri}

Tasfiye değeri, şirketin varlıklarının açık artırma ile satıldı̆̆ında toplam değerinden yükümlülüklerinin çıkarılması ile bulunan değere karşıllı gelmektedir (Ercan vd., 2003; Ertuna, 1986; Gönenli, 1991). Tasfiye işlemi organize bir şekilde belirli bir zaman dilimine yayılı olarak yapılırsa tasfiye işleminden daha fazla satış geliri elde edilir. Çok kısa sürede yapılan tasfiye işlemi zorlamayı gerektirir ve genellikle daha az satış geliri sağlar. Bu nedenle, tasfiye değeri bir şirketin minimum değerine karş1lık gelmektedir (Öztürk, 2009). Piper ve Fruhan'1n (1981) belirttiği üzere; tasfiye değeri, şirketin tasfiye edilmesi söz konusu olduğunda kullanılması uygun bir değer türü olmaktadır.

\section{Yeniden Yapma Değeri}

Yeniden yapma değeri, mevcut bir tesisin yenilenmesi için üstlenilecek maliyetlerin toplamına karşıllk gelen bir değer türüdür (Yazıc1, 1997). Örnek vermek gerekirse, 10 yıl önce tamamlanan bir tesisin kurulu değeri 100.000.000 TL ve söz konusu dönemde TL'deki enflasyon artış1 yüzde 20 ise, söz konusu tesisin bugünkü değeri $(100.000 .000 \times 1,20)=120.000 .000$ TL olacaktır. Bu değer türü, genelde şirket varlıklarını sigorta eden sigorta şirketleri ile hurda haline gelmiş, eskimiş varlıklar üzerine yeni bir işletme kurmayı planlayanlar açısından önemli olmaktadır.

\section{İşleyen Teşebbüs Değeri}

Faaliyetlerine devam eden bir şirketin değeri, onun varlıklarının dışında işleyişini de kapsayan bir değer türüdür. İşleyen teşebbüs değeri, şirketin bir bütün olarak devredilmesi halinde hesaplanan bir değer türü olmaktadır (Gacar, 2009; Gönenli, 1991). Bu tanımdan hareketle, faaliyette bulunanbir şirketin değeri, söz konusu şirketin bölümlerinin değeri toplamından daha fazla olacaktır. Bu şekilde 
değerde görülen farklılık, söz konusu şirketin bölümleri arasındaki sinerji etkisi ile açıklanabilir. Bu değer türünde şirketler; şerefiye, müşteri portföyü ve faaliyetlerine devam edeceği için bir değere sahiptir. Şirketin şerefiye değeri, faaliyet halindeki şirketten ayrı düşünüldüğünde, değeri az ve maddi olmayan bir varlıktır. Ancak, bu her şirket için geçerli değildir. Bazı şirketlerin şerefiye değeri, şirketin maddi varlıklarından çok daha fazla olabilmektedir. Örneğin; Apple, Amazon, Google ve Microsoft gibi şirketlerin değerinin yarıdan fazlasını şerefiye değeri oluşturmaktadır. Tanım olarak, işleyen teşebbüs değeri ile net aktif değeri arasındaki fark şirketin şerefiye değerini verir (Cesur, Tekindağ ve Ergün, 1999). Şirketlerde şerefiye değerinin kaynağını entellektüel sermaye oluşturmaktadır (Aşıkoğlu ve Aşıkoğlu, 1998).

\section{Emsal Değeri}

Emsal değeri, gerçek bedeli bilinmeyen veya bilinemeyen bir varlığın satılması durumunda benzerlerine göre sahip olacağı değer olarak tanımlanmaktadır (Seyidoğlu, 1992; Öztepe ve Beylik, 2014). Değerlemeye konu mal veya varlığın benzerlerinin piyasada yaygın olması durumunda, benzer mal veya varlıkların değeri referans olarak alınabilir. Bu yöntem taşı ve gayrimenkuller için daha yaygın kullanılmaktadır (Yazıcı, 1997). Örneğin; bu yönteme göre bir taşıt veya arsanın değer tespiti, çevresindeki benzer taşıt ve arsaların en son alım ve satım fiyatları dikkate alınarak yapılabilir. Şirket değerlemesinde ise, aynı sektörde benzer faaliyetlerde bulunan, şirket yapıları birbirine benzeyen ve daha önce değerlemeye konu olmuş şirketler için bir kriterin belirlenmesi ile şirket değerinin tespiti yapılabilir. Yazıcı (1997) tarafından çimento sektöründe ton başına, telekomünikasyon sektöründe hat başına değerin tespit edilmesi ile değerleme yapılabileceği belirtilmiştir.

\section{Ekspertiz Değeri}

Ekspertiz değeri, bir uzman tarafindan herhangi bir mal veya varlı̆ga değerleme gününde biçilen değere karşılık gelmektedir (Öztepe ve Beylik, 2014).Bu değer türü uzman görüşüne dayalı olması nedeniyle sübjektif bir değer olmaktadır. Diğer taraftan, bu değer türü piyasanın durumunu, mal ve/veya hizmetleri veya yönetimin becerilerini dikkate almamaktadır (Alkan ve Demireli, 2007).

\section{Net Aktif Değeri}

Net aktif değeri, bir şirketin varlıklarının değerinden tüm yükümlülüklerinin çıkarılması ile bulunan değerdir (Öztürk, 2009). Şirketin mevcut durumu ve değerleme zamanından itibaren şirkete ilave değer yaratılmayacağı varsayımı altında net aktif değeri, şirketin mevcut varlıkları tasfiye edilip tüm borçlarının ödenmesinden sonra kalan değere karşıllık gelmektedir.Net aktif değeri hesaplanırken dikkate alınması gereken en önemli kriter, şirketin varlık ve yükümlülüklerinin gerçek değerinden değerlemesinin yapılmasıdır (Öztürk, 2009). Yüksek enflasyona sahip ülkelerde, şirket varlıklarının gerçek değeri mevcut muhasebe yöntemiyle tutulan defter değerine eşit olmayabilir. Kasa, banka, menkul kıymet ve hemen paraya çevrilebilir varlıklar, gerçek değeri ile defter değeri birbirine yakın olan varlıklardır. Ancak, stoklar açısından durum farklıdır. Stok kapsamında yer alan hammadde ve mamul madde gibi varlıkların muhasebe kayıtlarında yer alan değerleri yerine piyasa rayiç bedelinden değerlemesi yapılmalıdır. Bu amaçla, piyasada benzer şirketlerin stok değerleri veya ilgili hammadde veya mamul maddelerin satış fiyatları alınabilir. Şirketin sabit kıymetlerinin değerini tespit etmek daha zordur (Öztürk, 2009). Bu durumda, sabit kıymetlerin piyasa rayiç bedelleri bağımsız bir ekspertiz analizi ile belirlenmelidir.

\section{Piyasa Kapitalizasyon Değeri}

Bir şirketin hisse senetlerinin borsaya kote olması durumunda, o şirketin hisse senetlerinin sayısı ile hisse senedinin piyasa cari fiyatının çarpımı, o şirketin cari tarihteki piyasa kapitalizasyon değerine karşılık gelmektedir (Ercan ve Ban, 2005; Öztepe ve Beylik, 2014). Örnek vermek gerekirse, bir şirketin hisse senedi sayısı 10.000 .000 adet ve hisse senedinin piyasa cari fiyatı 5 TL ise, söz konusu şirketin piyasa kapitalizasyon değeri $=10.000 .000 \times 5=50.000 .000 \mathrm{TL}$ olacaktır. Bu yönteme göre belirlenen değer, şirket değerini en iyi yansıtan değer olarak görülmektedir (Ercan ve Ban, 
2005).Bir şirketin hisse senetleri borsaya kote edilmemişse ve hisse senetlerinin halka arz yolu ile piyasada fiyatının oluşması mümkün değilse, bu durumda Yazıcı (1997) tarafından şirketin yıllık kazançlarının, faaliyette bulunulan sektörün genel karlılık oranına bölünerek söz konusu şirketin değerininhesaplanabileceği belirtilmiştir.

\section{Şirket Değerlemesinin Nedenleri ve Stratejik Önemi}

İşletmeler ekonomik amaç güden, maddi ve entellektüel varlıkları ile birlikte karmaşık ve dinamik organizasyonlardır (Pratt, 1998). İşletmeler faaliyetlerini yerine getirirken ekonomik ortam yanında sosyal ve yasal bir ortamda faaliyette bulunmaktadır. Şirket ile tüketiciler ve devlet arasındaki ilişkilerde ekonomik ölçütler dışındaki değer ölçütleri etkili olabilmektedir. Çevreye duyarlı ve vergi yükümlülüğünü yerine getiren bir şirket, toplum ve devlet tarafından güvenilir gibi değer ölçüleri ile değerlendirilir.Diğer taraftan, ekonomilerin dışa açılması ile birlikte ülkeler arasında etkileşim ve ekonomik faaliyetler artmaktadır. Bu gerçek; şirket yönetimi ile hissedarları ve devlet organlarının şirket değerlemesi ile ilgili konularla daha sık karşılaşmalarının nedeni olmaktadır (Lalik, 1973). Bir bakıma şirket değerinin belirlenmesi bazı durumlarda toplumun tamamını, bazı durumlarda ise belirli bir kesimini ilgilendirmektedir.Bir şirketin değerlemesini gerektiren birçok neden bulunmaktadır. Bunlardan bazıları; şirketin tüm varlıklarının veya bazı varlıklarının satışı, yeni hisse senedinin satış kararı, yeni hisse senedinin çıkarılma zamanı, şirketler arası birleşme ve satın almalardır(Piper ve Fruhan, 1981; Ercan vd., 2003). Ayrıca yeni şirket kurulması, yeni yatırım firsatlarının araştırılması, şirkete ortak alınması veya mevcut ortakların şirketten ayrılması, şirket hisselerinin mirasçılar arasında paylaşılması, özelleştirme, tasfiye, ipotek, şirketin sigorta değerinin hesaplanması, şirket hisselerinin borsada işlem görmek üzere kaydedilmesi ve vergi denetimi gibi işler değerlemeyi gerektiren nedenler arasında sayılabilir (Cesur, 1983; Piper ve Fruhan, 1981). Bunun yanında, şirkette yeni bir kar dağıtım oranıbelirlenmesi çerçevesinde şirketin toplam değerinin belirlenmesi gerekli olabilir (Dalgeç, 1992).

Şirket yönetiminin kaynak tahsisine yönelik olarak aldığ 1 her türlü karar şirketin değerini değiştirmektedir. Kararın türünden bağımsız olarak, yeni bir ürünün piyasaya sürülmesi, araştırma ve geliştirme yatırımı, yeni yatırım ve stratejik işbirliği konularında alınacak kararlar şirket değerini etkilemektedir (Monnery, 1997). Bu itibarla, şirketin sahip olduğu üretim kaynaklarının tahsisine yönelik karar alma sürecinde alınacak kararın şirket değerini etkilediği dikkate alınmalıdır.Günümüzde değerleme işi şirket yönetiminin öğrenmek ve uzmanlaşmak zorunda olduğu, finansal ve analitik bir yetenek durumuna gelmiştir. Artık değerleme işi ara sıra yapılan bir iş olmaktan çıkmış veişletmelerde kaynak tahsisi kararlarının alınmasında incelenmesi gereken bir ön koşul haline gelmiştir.Ercan ve diğerlerinin (2003) belirttiği üzere, artık günümüz yöneticileri içinkar maksimizasyonu amacı yerini değer maksimizasyonu amacına bırakmıştır.

Yöneticilerin hisse değerinin artırılmasına stratejik bir bakış açısı getirmesi, bu bağlamda değerin artırılması için şirketin önünde duran firsatların tespiti ve bunlardan yararlanma yollarının araştırılması gerekmektedir (French ve Ward, 1995). Stanley ve Olson'un (1996) belirttiği üzere nakit akımı yöntemi ve ekonomik katma değer (EVA) gibi geliştirilen teknikler yardımıyla yöneticiler şirketlerin hangi bölümlerinin şirket değerine katk1 yapıp, hangilerinin yapmadığını belirleyebilmektedir. Şirketler bu teknikleri yeni stratejilerin veya yeni üretim hatlarının oluşturulmasında da kullanabilmektedir (Stanley ve Olson, 1996).

\section{Ana Şirket ile Bağlı Şirketlerin İlişkisi Açısından Şirket Değerlemesi}

Değerlemenin işletmeler açısından stratejik önemine ilişkin üzerinde durulan konulardan biri de ana şirket değeri ile ilgili çalışmalardır. Bir ana şirket çatısı altında birçok bağlı şirketin sinerji etkisi ile merkezi olarak yönetilmelerinin bağlı şirketlerin teker teker değerlerinin üzerinde değere sahip olacakları savı her zaman geçerli olmamaktadır (Campbell, Gooldve Marcus, 1995).Bazı durumlarda ana şirketin bağlı şirketlerin değerini azalttığı ve ana şirkete bağlı şirketin bağımsız bir şirket olması veya başka bir şirketin portföyünde yer almasının bağlı şirketin değerini artırabileceği belirtilmektedir (Campbellvd., 1995). 
Campbellve diğerlerinin (1995) vurguladığı gibi, bağlı şirketin stratejisinin belirlenmesi, üst yönetiminin atanması, performans hedeflerinin belirlenmesi gibi bağlı şirketin işlerinin merkezden yapılması durumunda bazen yanlış kararlar alınarak ana şirketin değeri azalabilmektedir. Ayrıca ana şirketteki üst yönetimin bağlı şirketin faaliyet alanı ile ilgili yetersiz bilgi ve deneyime sahip olduğu durumlarda, hatalı kararlar alınması sonucu ana şirketin değeri azalabilmektedir.Farklı faaliyet alanında yer alan bağlı şirketler arasında sinerji oluşturulması ve işbirliği sağlanmasına yönelik girişimlerde hatalı kararlar alınması ile ana şirketin değerinde azalma olabilir. Merkezi olarak ana şirkette bazı fonksiyonların yürütülmesi ve hizmetlerin sunulması ana şirketin değerini arttırmayabilir. Bağlı şirketlerin piyasa şartlarındatemin edebileceği mal ve hizmetlerin gecikmeli ve rasyonel olmayan şekilde alınması da, ana şirketin değerini azaltıcı etki yapabilir(Campbellvd., 1995). Bazen ana şirket iyileştirme ve geliştirme adına şirket satın alma, birleşme, stratejik işbirliği, ortak girişim tipi şirketleşmeler konusunda da hatalı kararlar alarak ana şirket değeri azaltılabilmektedir.Ana şirket seviyesinde ölçek ekonomisinden yararlanarak satın almada müzakere gücü elde edilmesi, alınacak kredi maliyetlerinin düşük olması ve bağlı şirketin faaliyet alanı ile ilgili kararların ana şirkette başka bir bakış açısı ile incelenmesi ana şirket değerini artıran unsurlar olmaktadır(Campbellvd., 1995).

\section{Özelleştirme Açısından Şirket Değerlemesi}

Şirket değerlemesinin zorunlu olduğu alanlardan biri de özelleştirme faaliyetidir. Özelleştirmenin genel kabul gördüğü günümüzde şirket değerlemesi konusu hiç gündemden düşmeyen bir konu olmaktadır. Kamuya ait iktisadi varlıkların değerlemesi kamuoyunda dikkatle izlenmekte ve kamu mallarının gerçek değeri üzerinden özelleştirilmesi istenmektedir.Ayrıca Spencer (1994)'ın vurguladığı gibi özelleştirmenin başarısı uygun değerleme yönteminin kullanılmasına bağlı olmaktadır.Dünyada özelleştirmede elde edilen başarının, varlık ve hisse senedi değerlemesi konusunda elde edilen başarıya bağlı olduğu görülmüştür (Spencer, 1994). Özelleştirme uygulamalarının başarısı uygulanacak özelleştirme yönteminden ziyade değerleme işinin başarısında yatmaktadır (Spencer, 1994). Değerleme işinde toplumun tüm kesimlerince kabul görecek bağımsız değerleme yöntemlerinin kullanılması gerekli olmaktadır.

Türkiye'de özelleştirme çalışmaları kapsamında değerleme faaliyetleri 4046 sayılı Özelleştirme Uygulamaları Hakkında Kanunda düzenlenmiştir (Mevzuat Bilgi Sistemi, 1994). Bu kanunun 18 inci maddesinin birinci fikrasının b) bendinde, özelleştirme programına alınan kuruluşların değer tespit işlemlerinin, bu kuruluşların nitelikleri ve bunlara uygulanacak özelleştirme yöntemlerinin de dikkate alınarak yapılması hükmü getirilmiştir. Söz konusu kanun, değer tespitinde kullanılacak değerleme yöntemlerini çok geniş tutarak, her şirketin veya varlığın niteliğine uygun bir yöntemin uygulanmasına olanak tanımaktadır.Söz konusu kanunda genel kabul görmüş değerleme yöntemleri; indirgenmiş nakit akımları (net bugünkü değer), defter değeri, net aktif değeri, amortize edilmiş yenileme değeri, tasfiye değeri, fiyat/kazanç oranı, piyasa kapitalizasyon değeri, piyasa değeri/defter değeri, ekspertiz değeri ve fiyat/nakit akım oranı olarak teker teker sayılmıştır (Mevzuat Bilgi Sistemi, 1994). Kanunda sayılan bu yöntemlerden en az ikisinin uygulanması suretiyle değerleme yapılması öngörülmüştür. Kanun hükümleri çerçevesinde değer tespit sonuçlarının, ilgili kuruluşun özelleştirme işlemi tamamlanarak devir sözleşmesinde yer alan yükümlülüklerin yerine getirilmesinden sonra kamuoyuna duyurulması gerekmektedir.

\section{Değerleme Yaklaşımları ve Şirket Değerleme Yöntemleri}

Değerleme yöntemleri maliyet, gelir ve piyasa gibi çeşitli yaklaşımlara dayanmaktadır (Bilir ve Kulal1, 2014; Cesur vd., 1999). Şirket değerlemesinde bu yaklaşımların biri veya birkaçının bileşiminden oluşan bir yöntem kullanılmaktadır. Bu yaklaşımlar birbirinden farklı olmayıp birbirini tamamlayıc niteliktedir (Cesur, 1983).

Maliyet yaklaşımında, değeri belirlenecek varlığın yeniden yapma değerinin belirlenmesinden sonra varlığın fiziki, ekonomik ve fonksiyonel olarak kaybettiği değeri ölçülmektedir. Bu yaklaşımda, şirketin gelecek yıllardaki karları yerine şirketin varlıklarının maliyet değeri ve piyasa değeri ön plana çıkmaktadır. Ayrıca bu yaklaşımın; demir-çelik fabrikası, nükleer reaktör, elektrik üretim tesisleri gibi 
yüksek derecede uzmanlık gerektiren sektörler için uygun bir değerleme yaklaşımı olduğu kabul edilmektedir (Cesur, 1983).Gelir yaklaşımında, değerlemeye konu varlığın gelir sağlama kapasitesi dikkate alınmaktadır. Varlıklar, gelir elde ettikleri sürece bir değer ifade edecekleri için şirketin gelecekte elde edeceği nakit girişlerinin önemli bir faktör olduğu ve şirketin değerini bu potansiyel nakit girişlerinin oluşturduğu kabul edilmektedir (Piper ve Fruhan, 1981; Sirel, 1992). Bu yaklaşımda değer, varlığın ekonomik ömrü boyunca sağlayacağı gelirlerin bugünkü değerine karşılık gelmektedir (Bilir ve Kulalı, 2014). Şirketin varlık değeri yerine gelir getirici faaliyetleriyle ilgilenen yatırımcılar için bu yaklaşım önemli olmaktadır. Bu yaklaşım; sözleşme, lisans ve marka anlaşmaları, patent, ticari marka ve telif hakları ile imtiyazların değerlemesi için uygun bir yaklaşım olmaktadır (Yazıcı, 1997).Piyasa yaklaşımı için işleyen bir piyasanın olması ve varlıkların değişiminin yapılabilmesi gereklidir. Değerlemeye tabi tutulacak varlığın benzerlerinin piyasa fiyatı varsa, piyasa yaklaşımı değerlemede iyi bir gösterge olmaktadır(Yazıc1, 1997). Bu yaklaşımın; gayrimenkul, genel amaç için kullanılan makine ve teçhizat, bilgisayar donanımları ve taşıtların değerlemesi için uygun bir yaklaşım olduğu kabul edilmektedir (Yazıc1, 1997).

Şirket değerlemesi yöntemlerinden birinin seçimi;eldeki mevcut veri,değerlemesi yapılacak şirketin içinde bulunduğu şartlar, değerlemenin amacı ve değerlemesi yapılacak şirketin türüne bağlıdır. Bu yöntemler ile hesaplanacak değerler kullanılarak şirket için bir değer aralığına ulaşılabilir. Her şirket için uygun ve geçerli olacak bir değer hesaplama tekniği geliştirmek olanaklı değildir. Özellikle, her ülkede uygulanan vergi oranı, amortismana ilişkin mevzuat farklı olduğundan böyle bir tekniğin geliştirilmesi zor olacaktır.Yukarıda bahsedilen yöntemler yanında, Süel'e (1995) göre ticari karlılık analizi amacı ile değerleme yöntemlerini 3 ana grupta incelemek olanaklıdır. Bunlar indirgenmiş nakit akımı ile kazanca ve varlığa dayalı değerleme yöntemleridir. İndirgenmiş nakit akımına dayalı şirket değerleme yönteminde şirketin değeri, şirketin gelecekteki nakit akımları ile sermayenin alternatif maliyeti dikkate alınarak hesaplanır. Kazanca dayalı değerleme yönteminde, şirketin faaliyetine devam edeceği ve gelecek yıllarda pozitif nakit akımı sağlayacağı dikkate alınarak şirket değeri hesaplanır. Bu yaklaşımda kullanılan yöntemler için fiyat/kazanç oranı, piyasa değeri/defter değeri oranı, temettüye dayalı yöntem örnek olarak verilebilir. Varlığa dayalı değerleme yöntemi, faaliyet değeri düşük veya olmayan, ancak varlık değeri olan şirketler için uygun bir yöntem olmaktadır. Bu kapsamda kullanılan yöntemlere net aktif ve tasfiye değerleri örnek olarak verilebilir (Süel, 1995).Bu çalışmada; şirket değerleme yöntemi olarak bilanço yöntemi, temettüye dayalı değerleme yöntemi, göreceli değerleme yöntemi, nakit akımı yöntemi ve finansal performans ölçümüne dayalı yöntem incelenmiştir.

\section{Bilanço Yöntemi}

Bilanço yöntemi kapsamında, defter değeri ile piyasa değeri cinsinden net maddi değer ele alınabilir. Ayrıca bilanço yöntemi varlık ve yükümlülüklere dayalı olduğundan Masun'un (2017) da belirttiği üzere, tasfiye ve net aktif değerleri de bilanço yöntemi kapsamında incelenebilir.Bu yöntem kapsamda yer alan defter değeri; bir şirketin değerini hesaplamada kullanılan basit ve uygulanması kolay bir yöntemdir. Defter değeri, muhasebe kayıtlarına göre şirketin toplam varlıkları ile toplam yükümlülükleri arasındaki farka eşit olmaktadır (Öztürk, 2009).

Defter değerinin belli başlı eksikliklerini şu şekilde sıralamak mümkündür. Bu yöntem, Piper ve Fruhan'ın (1981) belirttiği üzere bazı varlıkların ekonomik değerini doğru yansıtmamaktadır. Bu eksiklik geleneksel muhasebe yönteminin güncel ekonomik değerlerden ziyade tarihi değerler bazında yapılan kayıtlara dayalı olmasından kaynaklanmaktadır. Bu eksikliğine rağmen defter değeri gerçekçi bir değer tespitinde başlangıç noktasını oluşturabilir. Hatta defter değeri, diğer yöntemler kullanılarak bulunan değerler ile karşılaştırma yapmak için bir referans değer olarak düşünülebilir.Defter değeri tek başına bir şirketin değerinin hesaplanmasında yararlı olmamaktadır. Ayrıca, defter değeri şirketin sermayesi üzerinden ne kadar kar elde edildiğini de yansıtmamaktadır. Bu nedenle defter değeri, şirketin karlılığını ve yeni yatırım firsatlarını dikkate almadığından uygun bir değerleme yöntemi olarak görülmemektedir (Piper ve Fruhan, 1981). 
Bilançoda varlık ve yükümlülüklerin ekonomik değerinin doğru yansıtılması için bazı düzenlemeler yapılması gerekmektedir. Bu şekilde düzenleme yapılarak bulunacak piyasa cinsinden net maddi değer, defter değerinden fazla veya az olabilir. Bu kapsamda maddi olmayan varlıkların çıkarılmasına ek olarak değeri azaltacak unsurlar şunlardır; tahsil edilemeyen alacaklar ile kayıt altına alınmamış borç ve yükümlülüklerdir. Diğer taraftan, defter değerine göre değeri arttıran bilanço kalemleri stoklar ile sabit varlıklardır. Bu şekilde yapılacak bir düzeltme işleminin en önemli avantajı varlıkların daha doğru ekonomik değerlerini yansıtmasıdır. Ancak, bu yöntemde de defter değerinde olduğu gibi şirketin varlıkları üzerinden makul ölçüde ekonomik gelir elde edilmesihususu dikkate alınmamaktadır.Bilançosunda maddi olmayan varlık tutarı diğer varlıklara göre fazla olan şirketler için bu yöntemin uygun bir yöntem olmayacağı düşünülmektedir.

Bilançoya bağlı olarak hesaplanabilecek diğer değer türü tasfiye değeridir. Yukarıda da belirtildiği üzere; tasfiye değeri, bir şirketin tasfiye edilmesi söz konusu olduğunda kullanılması uygun olan bir değerleme yöntemidir. Tasfiye sürecine giren bir şirketin değerinin mümkün olduğunca artırılması amacıyla söz konusu şirketin varlıklarının satışından yüksel gelir sağlanması hedeflenir. Diğer değer türü net aktif değerini hesaplamak için bir şirketin varlıklarının değerinden tüm yükümlülükler çıkarılır.Bu yöntemde en önemli kriter, Öztürk'ün (2009) de vurguladığı gibi şirketin varlık ve yükümlülüklerinin gerçek değerinden değerlemesinin yapılmasıdır.Dünya ekonomisinde üretim sektöründen hizmet sektörüne geçiş hızlandıkça şirket değeri artan oranda şirket çalışanlarında yoğunlaşmaktadır. Örneğin; Apple, Amazon, Google, Microsoft, Disney World ve Marks \& Spencer gibi firmalar başarılarını entellektüel mülkiyet ve kamuoyundaki imajlarına borçludurlar. Ancak, bu tür varlıklar bilançoda yer almamaktadır. Diğer taraftan, enflasyon ile farklı stok ve amortisman uygulamaları bilançoyu değerlemede yanıltıcı bir araç haline getirmektedir. Bilançoya dayalı değerleme yönteminin en önemli yetersizliği varlıklardan gelir elde etme gücünü dikkate almamasıdır.

\section{Göreceli Değerleme Yöntemi}

$\mathrm{Bu}$ yöntemin esası, değerlemeye konu şirketin değerlemesinde aynı sektörde faaliyette bulunan bir şirketin değerinin referans alınmasıdır. Bu yöntemin işlerlik kazanabilmesi için aynı sektörde faaliyette bulunan vedeğerleme için referans alınabilecek şirketlerin bulunması gerekmektedir (Aydın, 2012). Bilir ve Kulalı'nın (2014) belirttiği üzere, bu yöntem üç aşamada uygulanmaktadır. İlk aşamada karşılaştırma yapılacak şirketler belirlenmekte, ikinci aşamada karşılaştırmada kullanılacak standart oranlar belirlenmekte, üçüncü ve son aşamada hedef şirketin oranları ile sektör ortalaması karşılaştırılmaktadır. Bu şekilde değerlemeye konu varlığın düşük veya yüksek değerlenip değerlenmediği bilinmektedir (Bilir ve Kulalı, 2014; Öztürk, 2009). Bu çalışma kapsamında; fiyat/kazanç oranı, piyasa değeri/defter değeri oranı ve fiyat/nakit akımı oranı bu yönteme örnek olarak alınmış ve incelenmiştir.

\section{Fiyat/Kazanç Oranı Yöntemi}

$\mathrm{Bu}$ yöntemin esası, şirket değerinin aynı şirketin kazancı ile ilişkilendirilmesine dayanmaktadır (Öztürk, 2009). Fiyat/Kazanç $(F / K)$ oran1, şirketin bir birim hisse senedi başına düşen net karına karşılık yatırımcının ödemeyi kabul ettiği tutarı gösteren bir orandır. Bu yöntemde, hisse senedi başına net kar piyasada gerçekleşmiş olan fiyat/kazanç oranıyla çarpılarak, hisse senedinin olması gereken değeri bulunur. Bu yöntemde hissedarlar açısından şirket değeri $(V)$, şirket net dönem karı (NI)olmak üzere aşağıda verilen formüle göre hesaplanır.

$$
\text { 1) } V=\left(\frac{F}{K}\right) x N I
$$

Örnek vermek gerekirse; şirket net dönem karı (NI)10.000.000 TL, hisse senedi sayısı 25.000.000 adet ve $(F / K)$ oranı 11 ise şirket değeri $(V),(1)$ no'lu formül yardımıyla $V=(11 \times 10.000 .000$ $\mathrm{TL})=110.000 .000 \mathrm{TL}$ olarak hesaplanır.Bir adet hisse senedinin değeri $(110.000 .000 / 25.000 .000)=4,4$ TL olarak hesaplanır.Alternatif olarak bir adet hisse senedinin değeri $=\{(F / K) x h i s s e$ senedi başına net dönem $\operatorname{kar} 1=\{11 \times(10.000 .000 / 25.000 .000)\}=(110.000 .000 / 25.000 .000)=4,4$ TL hesaplanır. Etkin 
sermaye piyasası varsayımı altında, piyasa değeri şirketin gerçek değerini yansıttığı için bu yönteme göre hesaplanan değerin daha gerçekçi olduğu savunulmaktadır. $F / K$ oranı yöntemi ile şirket değerlemesinde, aynı sektörde faaliyet gösteren ve benzer şirketlerin $F / K$ oranları ortalaması, genel piyasa $F / K$ oranı ortalaması veya yurtdışındaki benzer şirketlerin $F / K$ oranı ortalaması alınabilir. Bu yöntem, halka açı olmayan şirketlere de uygulanabilir. Buna göre, şirketin hisse senetlerinin fiyatı belli değilse, şirketin faaliyette bulunduğu sektördeki $F / K$ oranından yararlanılarak şirketin hisselerinin değeri hesaplanabilir (Guatri, 1994). $F / K$ oranı yönteminin en önemli eksikliği, hesaplamalarda net dönem karının gösterge olarak alınmasıdır. Ancak, muhasebe uygulamalarındaki farklılıklara büyük ölçüde duyarlı olan net dönem karına dayalı tahminler ile faaliyet dışı gelir ve/veya giderleri fazla olan şirketlerin $F / K$ oranlarının değerlemede kullanılması yanıltıcı sonuçlar verebilir. Ayrıca, bu yöntem şirketin beklenen karlılığı hakkında herhangi bir şey ifade etmemektedir (Doğu, 1996). Bu yöntemin bir diğer sakıncası, $F / K$ oranı sabit olarak ele alınmakta ve zamana bağlı olarak değişimi dikkate alınmamaktadır. Başka bir ifadeyle, zaman ve risk boyutları bu yöntem ile değerlemede gözardı edilmektedir.

\section{Piyasa Değeri/Defter Değeri Oranı Yöntemi}

Piyasa Değeri/Defter Değeri $(P D / D D)$ oranı, hisse senedinin piyasa değerinin hisse başına öz kaynaklara bölünmesi ile bulunmaktadır. Bu yöntemde, şirketlerin $P D / D D$ oranının, aynı sektörde bulunan şirketler için aynı olduğu varsayımından hareket edilerek şirket değeri tespit edilmektedir (Alkan ve Demireli, 2007). Bu yöntem ile şirket değerinin hesaplanması için $P D / D D$ oranının, şirketin defter değeri ile çarpılması gerekir.Bu çarpım işleminde şirketin defter değeri yerine hisse senedi başına defter değerinin kullanılması halinde, hisse senedi değerine ulaşılır. Bir şirketin $P D / D D$ oranının, o sektörde faaliyette bulunan diğer şirketlere kıyasla yüksek olması, o şirketin hisse senetlerinin fiyatının şişkinliğinin bir göstergesi olmaktadır.Bu yöntem kullanılırken, şirketlerin varlıklarını en iyi şekilde kullanacakları varsayımı yapılmaktadır. Her şirketin kendine özgü özelliklerinin olması ve varlıklarını aynı verimlilikte kullanamaması, bu yöntemin zayıf tarafinı oluşturmaktadır. $P D / D D$ oranı yöntemi, enflasyonun yüksek olduğu dönemlerde net kara dayalı değerlemeden kaçınmayı sağlaması açısından avantajlı görülmektedir.

\section{Fiyat/Nakit Akımı Oranı Yöntemi}

Bu oran esas itibariyle $F / K$ oranına dayalı değerlemeye benzemektedir. Ancak, bu yöntemde şirket değeri kazanç yerine şirketin nakit akımı ile ilişkilendirilmektedir. Bu şekilde,fiyat/nakit akımı oranı kullanılarak benzer şirketlerin değeri hesaplanmaktadır. Bu yöntemde, benzer şirketlerin hisse senedi fiyatı ile nakit akımları oranı hesaplanarak, değerlemeye konu şirketin nakit akımı ile bu oranın çarpımı sonucu şirket değeri bulunur (Alkan ve Demireli, 2007; Öztürk, 2009). Fiyat/kazanç oranı ile piyasa değeri/defter değeri oranı yöntemlerinde yapılan hesaplamalar aynı şekilde fiyat/nakit akımı oranı yöntemine de uyarlanabilir.

\section{Temettüye Dayalı Değerleme Yöntemi}

$\mathrm{Bu}$ yöntemin dayanağını; kar dağıtımının şirketin hisse senetleri değeri üzerinde etkili olduğu ve hisse senedinin bugünkü değerinin, beklenen temettülerin bugünkü değerine eşit olması oluşturmaktadır (Öztürk, 2009). Hisse senetlerine temettü elde etme, sermaye kazanc1 elde etme ve bedelsiz sermaye artırımlarından faydalanma amacıyla yatırım yapılır. Türkiye'de sermaye piyasalarında işlem gören şirketler için yapılan bir araştırmaya göre, dağıtılan temettülerin hisse senetleri fiyatları üzerinde etkili olduğu gözlenmiştir (Doğukanlı, 1994). (Div)hisse başına temettü ödemesine ve $r$ indirgeme faktörüne karşılık gelmek üzere, temettüye dayalı hisse senedi değeri $(P)$ formül olarak şu şekilde yazılabilir (Akgüç, 1989).

2) $P=\frac{D i v_{1}}{(1+r)^{1}}+\frac{D i v_{2}}{(1+r)^{2}}+\ldots+\frac{D i v_{t}}{(1+r)^{t}}$ 
Divocari yıl için dağıtılmış hisse başına temettü tutarı ve Div ${ }_{1}$ gelecek yıl için hisse başına ödenecek temettü tutarı olması, ayrıca temettü ödemelerining oranında artacağı varsayımı altında (2)no'lu formülden (3)no'lu formül elde edilir.

3) $P=\frac{D i v_{1}}{r-g}=\frac{D i v_{0}(1+g)}{r-g}$

(3) no'lu formülde temettü ödemelerinin her yıl birbirine eşit olması halinde, başka bir deyişle $g$ artış oranının sıfır olması halinde (3) no'lu formül $P=(D i v o l r)$ haline dönüşür. Bu yöntem, sadece temettüyü ve temettüdeki artışı dikkate alan bir yöntemdir. (2) ve (3) no'lu formüllerden görüldüğü üzere, bu yöntem şirkette dağıtılmayan karları ve hisse senedi satış kazançlarını dikkate almamaktadır. $\mathrm{Bu}$ yöntemin temel başarısı, gelecek yıllarda dağıtılacak temettü miktarı ve temettü ödeme oranındaki tahmine bağlı olmaktadır. Bunun yanında, (3) no'lu formül dikkate alındığında temettüdeki artış oranının $(g)$, indirgeme oranına $(r)$ eşit olması durumundaşirket değeri sonsuz olarak hesaplanacaktır. $\mathrm{Bu}$ yöntem için örnek vermek gerekirse; cari yılda hisse başınatemettü ödeme tutarı $\left(\operatorname{Div}_{0}\right) 5 \mathrm{TL}$, temettüdeki artış oranı $(g) \% 10$ ve indirgeme oranı $(r) \% 20$ ise (3) no'lu formül kullanılarak hisse senedi değeri $\mathrm{P}=(5 \times 1,10) /(0,20-0,10)=55$ TL olarak hesaplanır. Şirketin hisse senedi sayısı ile bu değer çarpılarak hissedarlar açısından şirket değerine ulaşılır.

\section{Nakit Akımı Yöntemi}

Nakit akımı yöntemi en yaygın kullanılan değerleme yöntemidir (Ercan vd., 2003; Piper ve Fruhan, 1981). Bu yöntem, geleceğe yönelik fiyat ve maliyetlerin tahmin edilmesini ve indirgeme faktörü seçilmesini gerektiren bir yöntemdir.Ancak bu yöntem nakit akımının tahmin edilebildiği şirketlerin değerlemesi için uygun olmasına rağmen, yüksek büyüme firsatı veya maddi olmayan duran varlıkları olan şirketlerin değerlemesinde yetersiz kalmaktadır. Nakit akımı yönteminderisk yönetimi ve vadeli satış yapma olanakları ile işletmedeki iyileşmeler dikkate alınmamaktadır. $\mathrm{Bu}$ itibarla, nakit akımı yöntemi dışsal faktörlere karş1 şirket yönetiminin getirdiği esnekliğin değerini hesaplamada yetersiz kalmaktadır. Bu eksikliğin giderilmesi için opsiyon kavramına dayalı opsiyon fiyatlandırma yöntemi önerilmektedir (Cornell, 1993).Özellikle yüksek teknolojiye dayalı şirketlerin, finansal krizdeki şirketlerin ve doğal kaynaklar ile iştigal olan şirketlerin değerlemesinde bu teorinin kullanımı daha uygun olmaktadır.

Nakit akımı yöntemi ile şirket değerlemesinin esasını, net bugünkü değer (NPV) oluşturmaktadır. $N P V$ zenginlik, refah birikiminin bir ölçüsüdür. Torries (1998)'e göre ekonomik bakış açısından değerlemede $N P V$ nnin kullanılması teorik olarak daha doğru bir yaklaşım olmaktadır. Ancak, $N P V$ refahın hangi etkinlikle biriktiği hakkında bilgi veren bir fonksiyon niteliğinde değildir (Torries, 1998). $N P V$ 'nin büyüklüğü, karlılık ve ilk yatırım tutarının büyüklüğüne bağlı olmaktadır. Diğer taraftan, $N P V$ üretimin opsiyon değerini ve yatırımdaki esnekliği dikkate almamaktadır (Torries, 1998).

Geleneksel $N P V$ yönteminde enflasyona göre uyarlanmamış nakit akımları bugüne indirgenmektedir. İndirgeme oranı bütün dönemlerdeki nakit akımları için sabittir. Enflasyon primi indirgeme oranı içinde olup tüm dönemler için sabittir. Bu yöntemde ayrıca proje gelir ve giderlerinin enflasyona farklı duyarlılıkları ile işletme yönetim ve çalışanlarının deneyim ve becerisi dikkate alınmamaktadır. Bunun yanında, standart nakit akımına dayalı değerleme yönteminin bazı özel durumlarda güncellenmesi gerekmektedir. Bu hesaplama tekniği, gelirinde dönemsel dalgalanma görülen, finansal krizdeki ve özel ürün opsiyonuna sahip şirketler için amaca hizmet etmeyecektir (Damodaran, 1994; Damodaran, 1996). Kısaca NPV yöntemine göre şirket değerlemesini gelecekte oluşacak nakit akımının bugünden tahmin edilmesi ve el değiştirmesi olarak tanımlamak da mümkündür.

Nakit akımı yöntemi ile değerleme, üç temel parametrenin fonksiyonudur. Bu parametreler nakit akımı, zaman ve risktir (Üreten ve Ercan, 2000). Bu parametreler şirket yönetiminin alacağ1 kaynak tahsisi kararlarının her birinde farklı büyüklüklere sahip olacak ve neticede farklı değer 
hesaplanacaktır. Nakit akımı yöntemi kapsamında bugünkü değer,gelecek değer ve indirgeme oranı şu şekilde yazllabilir.

$$
\text { 4) } P V=\sum_{t=0}^{n} \frac{\left.E(C F)_{t}\right)}{(1+r)^{t}}
$$

(4)no'lu formülde; $t$ zamana, $(1+r)^{t}$ riske, $E(C F)_{t}$ beklenen nakit akımına ve $P V$ ise şirket toplam değeri $(V)$ 'nin bugünkü değerine karşlık gelmektedir. Şirket toplam değeri; özsermaye ve kredi değerlerinin toplamından oluşup Şekil3'de verilmiştir.

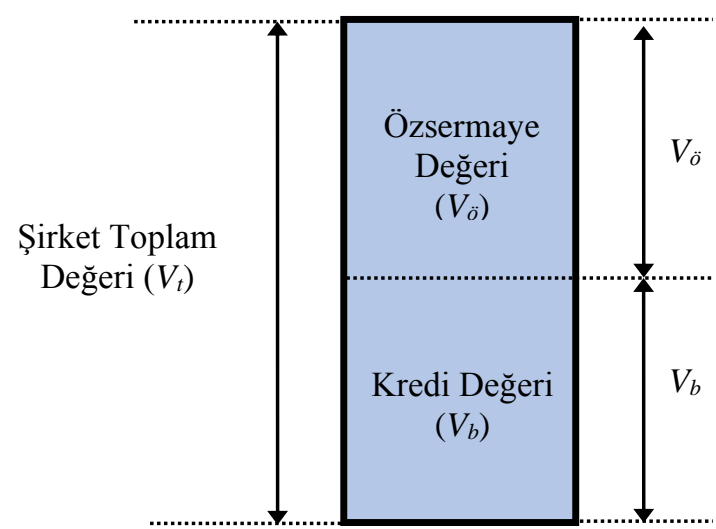

Şekil 3.Özsermaye ve Kredi Değerleri ile Şirket Toplam Değeri Arasındaki İlişki

Ayrıca, özsermaye ve kredi değerleri sırasıyla (5) ve (6) no'lu formüller ile ifade edilebilir.

$$
\begin{aligned}
& \text { 5) } V_{\mathrm{o}}=\sum_{t=1}^{n} \frac{C F_{S t}}{(1+r)^{t}}=\frac{C F_{S 1}}{(1+r)^{1}}+\frac{C F_{S 2}}{(1+r)^{2}}+\cdots+\frac{C F_{S n}}{(1+r)^{n}} \\
& \text { 6) } V_{b}=\sum_{t=1}^{n} \frac{C F_{b t}}{(1+r)^{t}}=\frac{C F_{b 1}}{(1+r)^{1}}+\frac{C F_{b 2}}{(1+r)^{2}}+\ldots+\frac{C F_{b n}}{(1+r)^{n}}
\end{aligned}
$$

(5) ve (6) no'lu formüllerde $r$ indirgeme oranına, $C F_{s t} t$ zamanında şirket hissedarlarına nakit akımına, $C F_{b t}$ ise $t$ zamanında şirket kreditörlerine nakit akımına karşlık gelmektedir. Şirket toplam değeri, şirket özsermaye değeri ile şirket kredi değerinin toplamıdır. Ayrıca, şirket toplam değeri $V_{o ̈}$ ve $V_{b}$ formüllerinin toplamı olarak $V_{t}=V_{s}+V_{b}$ şeklinde yazılabilir. Ayrıca bir şirketin toplam değeri $V_{t}$ $=V_{s}+V_{b}+V_{d}+V_{r}$ şeklinde de yazılabilir. $V_{t}$ formülünde, şirket nakit akımında $V_{s}$ hissedarların payına, $V_{b}$ kredi verenlerin payına, $V_{d}$ devletin payına, $V_{r}$ şirket ile ilgili diğer çıkar gruplarının menfaatlerinin değerine karşılık gelmektedir.Yukarıda ifade edilenler (7) no'lu formül şeklinde de ifade edilebilir.(7) no'lu formülde; $V$ şirket toplam değerini ve $C F_{t}$ tüm kesime nakit akımı toplamını ifade etmek üzere, $C F_{1}=C F_{2}=\ldots=C F_{t}$ olduğu ve $r^{\prime}$ nin değişmediği varsayımı altında(7) no'lu formül(8) no'lu formüle dönüşür.

$$
\begin{aligned}
& \text { 7) } V=\sum_{t=0}^{n} \frac{C F_{t}}{(1+r)^{t}} \\
& \text { 8)V }=\int_{0}^{n} \frac{C F_{t}}{(1+r)^{t}} d t
\end{aligned}
$$

$V$ 'nin bugünkü değerinin $t$ zamanına bağlı olarak değişimi Şekil4'de verilmiştir. 


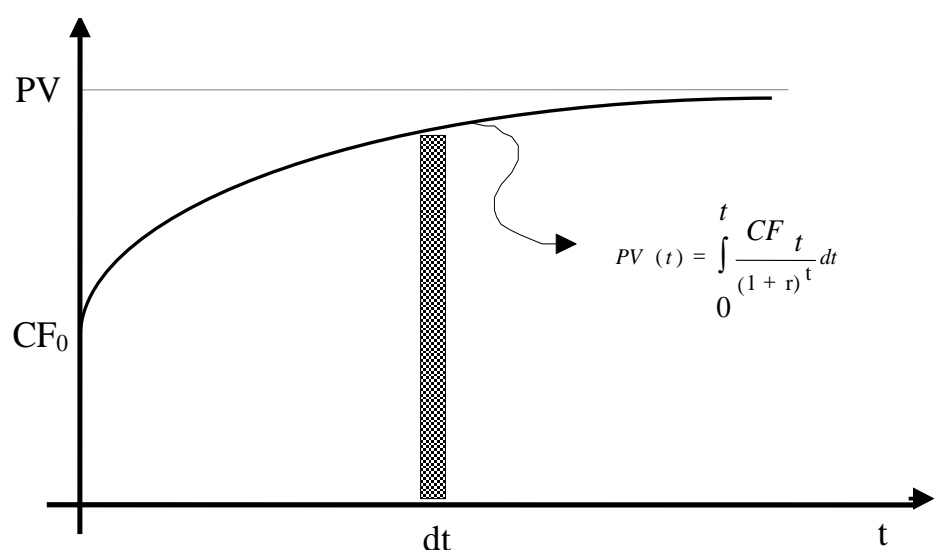

Şekil 4.Şirket toplam değeri $(V)$ 'nin bugünkü değerinin t Zamanı ile Değişimi

(8) no'lu formülde $C F_{t}=C F_{t-1}(1-g)$ veya $C F_{t}=C F_{t-1}(1+g)$ olmas1 halinde,

$$
\begin{aligned}
& (9) V(t)=\int_{0}^{n} \frac{C F_{t}(1+g)^{t-1}}{(1+r)^{t}} d t \\
& (10) V(t)=\int_{0}^{n} \frac{C F_{t}(1-g)^{t-1}}{(1+r)^{t}} d t
\end{aligned}
$$

formülleri elde edilir. (9) ve (10) no'lu formüllerin 1) $r=g$, 2) $r>g$ ve 3) $r<g$ durumları için farklı çözümler elde edilir.Şekil4'deki $P V(t)$ fonksiyonunun grafiğinden görüleceği üzere, $t$ zamanı arttıkça $P V(t)$ değerindeki artış azalmakta ve azalma miktarı zamanla ihmal edilebilecek seviyede olmaktadır. Nakit akımının ve $r$ değerinin zamanla değişmediği varsayımı altında, $V(t)$ fonksiyonunun $t$ 'e göre birinci türevi sıfira eşitlenerek, yani $V(t)$ fonksiyonunun eğiminin sıfir olduğu noktaya karşılık gelen $t$ değerini bulmak olanaklıdır. Hesaplama ile bulunacak $t$ değerinden sonra şirketin değerindeki artış ihmal edilebilecek mertebeye ulaşmaktadır. $V(t)$ 'nin $d t$ 'e göre türevini sıfira eşitleyen $t$ değeri bulunur. $\mathrm{Bu} t$ değeri şirket açısından kritik $t$ değeridir. Ancak $V(t)$ fonksiyonunun özelliği bu şekilde bir hesap yapmakta belirleyici olmaktadır. $\mathrm{V}(\mathrm{t})$ fonksiyonunun türü türev alınmasını ve sonuçta kritik $t$ değerinin hesaplanmasını olanaksız kılabilir. $C F(t)$ 'nin t zamanına bağlı sürekli bir fonksiyon olarak, $t=0$ 'a göre bugünkü değeri $C F(t) e^{-r t}$ olarak bulunur (Chiu ve Chen, 1997).

Diğer taraftan $d C F(t) / d t=r C F(t)$ olarak yazılabilir. Ayrıca $C F(t+\delta)=C F(t)+r C F(t) \delta, \delta \rightarrow 0$ yazılabilir. $C F(t)$ fonksiyonu $t \geq 0$ olmak üzere sürekli ve zamanın bir fonksiyonu olup, gelecekte $T$ zamanına kadar oluşacak nakit akımlarının, $r$ sürekli indirgeme oranı ile indirgenmesi ile oluşacak bugünkü değer $(P V)$,

$$
\text { 11) } P V=\int_{t=0}^{t=T} C F(t) e^{-r t} d t \text { elde edilir. }
$$

\section{Finansal Performansölçümüne DayalıYöntemler}

Finans yazınında şirket değerinin belirlenmesi yanında stratejik bakış açısı ile şirket değerinin yönetilmesi ön plana çikmaktadır (Öztürk, 2009; Üreten ve Ercan, 2000). Finansal performans ölçümüne dayalı yöntemlerin bu amaca hizmet eden yöntemler olduğu değerlendirilmektedir. $\mathrm{Bu}$ kapsama giren yöntemler; artık kar, ekonomik kar, ekonomik katma değer ve yatırımın nakit akım karlılı̆̆ 1 yöntemleridir (Öztürk, 2009). Bu yöntemler, değerleme yanında şirketin performansı hakkında bilgi veren ve $N P V$ 'den farklı olarak yıllık bazda hesaplanan yöntemlerdir.

Artık kar yöntemi, vergi sonrası faaliyet karından yatırılan sermayenin maliyet tutarının çıkarılmasına dayalı bir yöntemdir (Ercan vd., 2003). Matematiksel olarak artık kar $(R I)=$ faaliyet kart$\left(r_{w} \mathrm{x}\right.$ yatırılan sermaye) şeklinde ifade edilebilir (Öztürk, 2009).Bu formülde, $r_{w}$ ağırlıklı ortalama 
sermaye maliyetine karşılık gelmektedir.Artık kar, sermayenin firsat maliyetini dikkate alarak bir şirketin belirli bir dönemde yarattığı değeri ifade etmektedir (Öztürk, 2009). Öztürk'ün (2009) belirttiği üzere bir şirketin değer yaratması, ancak özsermaye ve borç maliyeti toplamından daha fazla getiri sağlanması halinde mümkün olacaktır.

Ekonomik kar yöntemi ile ekonomik katma değer yönteminin, artık kar yönteminden türetilen yöntemler olduğu anlaşılmaktadır. Ekonomik $\operatorname{kar}(E P)$ matematiksel olarak EP=yatırılan sermayex $\left(r_{a^{-}}\right.$ $r_{w}$ ) şeklinde ifade edilebilir (Üreten ve Ercan, 2000; Öztürk, 2009). Burada $r_{a}$ yatırılan sermayenin getirisine karşılık gelmektedir. EP, bir şirketin belli bir zaman diliminde yarattığı değeri ölçmektedir (Öztürk, 2009). EP'ye göre bir şirketin değeri, yatırılan sermaye ve öngörülen ekonomik karın bugünkü değerinin toplamına eşit olacaktır (Üreten ve Ercan, 2000).

Ekonomik katma değer (EVA) yöntemi de, esas itibarıyla şirket yönetiminin performansını belirlemek amaciyla geliştirilmiş bir yöntemdir (Coggan, 1997). EVAalternatif olarak şu şekilde açıklanabilir. Özsermaye ve kredi ile finanse edilen bir şirketin ağılıklı ortalama sermaye maliyeti $\left(r_{w}\right)$ ile yatırılan sermayenin getirisi $\left(r_{a}\right)$ arasındaki farkın $\left(r_{a}-r_{w}>0\right)$ sıfırdan büyük olması durumu şirketin değer kazanmasına karşılık gelmektedir. Başka bir deyişle, şirkette $\left(r_{a}-r_{w}\right)$ kadar değer artışı sağlanmış olunur (Young, 1997; Dierks ve Patel, 1997). Matematiksel olarak $E V A=\left(r_{a}-r_{w}\right)$ x (varliklarin ekonomik olarak defter değeri) şeklinde ifade edilebilir (Üreten ve Ercan, 2000).

$E V A$, hesaplama tekniği açısından $N P V$ 'den farklı bir yöntem değildir. $N P V$ proje veya şirketin ömrü boyunca oluşacak nakit akımını dikkate alan özet bir ölçü olmaktadır. Buna karşılıkNPV tüm ömür süresince ele alınan herhangi bir dönemde sağlanan performans hakkında bilgi vermemektedir. Bu bakımdan EVA, Milbourn (1997) tarafından belirtildiği üzereNPV'nin bu eksikliğini gideren bir yöntem olmaktadır. Diğer taraftan $E V A$, periyodik olarak şirketin hangi birimlerinin değer yarattığını belirlediğinden iyi bir performans ölçüm yöntemi olmakta, aynı zamanda işletmelerde değere dayalı yönetim anlayışının uygulanmasında kabul edilen ve kullanılan bir araç olmaktadır (Ercan vd., 2003).Milbourn (1997) tarafından EVA şirket yönetiminin kararları ile hissedar serveti arasında bağ kurmak için bir performans ölçümmodeli olarak görülmektedir. Bu bakımdan,EVA bir çeşit şirket içi ve dışı çevre arasında bilgi iletişim sistemi olmaktadır. Milbourn'ün (1997) belirttiği üzere, EVA'nın nakit akımına dayalı değerleme ile bulunan sonuçları değiştirmesi beklenmemekte ve bu açıdan bakıldığında, EVA yeni bir değerleme yöntemi olarak görülmemektedir.

Yatırımın nakit akım karlılığı modeli de sermaye maliyetini dikkate alan ve yıllık bazda hesaplanan bir yöntemdir. Öztürk (2009) tarafindan bu modelde,mevcut vergi sonrası enflasyona göre düzeltilmiş nakit akımlarının enflasyona göre düzeltilmiş sermaye maliyeti ile karşılaştırıldığı belirtilmiştir.Yukarıda belirtilen diğer yöntemler parasal değere karşılık gelmekte, ancak bu yöntem Monnery (1997) ve Öztürk (2009) tarafından belirtildiği gibi iç karlılık oranına benzer bir orana karşılık gelmektedir. Değer yaratan bir şirket için bu yönteme göre hesaplanacak oranın, şirketin sermaye maliyetinden daha büyük olması beklenir.

\section{Sonu, Tartışma ve Öneriler}

Günümüzde şirketler; çok sayıda değişkenin etkileşim halinde olduğu, dış çevreden şirkete ve şirketten dış çevreye uzanan bilgi, ürün ve hizmet gibi akımların zaman zaman kesintiye uğradığı, başka bir ifade ile belirsizliğin ve karmaşıklığın yüksek derecede olduğu bir ortamda faaliyette bulunmaktadırlar. Dolayısıyla, şirketlerin doğru planlama yapabilmesi ve doğru kararlar alabilmesi amacıyla bu tür ortamlarda şirket davranışlarını anlamaya yönelik çalışmalara ağırlık verilmesi ve yeni yaklaşımların geliştirilmesi gerekmektedir. Bu çerçevede, değişen ve gelişen şartlara uyum sağlayan yeni yöntem ve hesaplama tekniklerine ihtiyaç duyulmaktadır. İşletmelerde yeni yaklaşım ve yöntem gerektiren konulardan biri de şirket değerlemesidir.

Finans yazınında, işletmelerde şirket değerlemesine yönelik birçok yöntem önerilmiş ve bu yöntemler kullanılmaktadır. Şirket değerlemesinde kullanılan yöntemler teorik açıdan güçlü olup uygulamada karşılaşılan temel problem her yöntemin gerektirdiği girdi parametrelerinin uygun bir 
şekilde belirlenmesidir. Ayrıca; şirket değerlemesinin amacı, kim için değerleme yapılacağ 1 veşirketin içinde bulunduğu durum değerlemede hangi yöntemin kullanılacağını belirleyen temel kritik faktörler olmaktadır. Bunedenle, değerlemede kullanılacak yöntemler analiz edilmeli ve her bir yöntemin güçlü ve zayıf yönleri gözden uzak tutulmamalıdır.

Şirket değerleme işinde yaygın olarak nakit akımı yöntemi kullanılmaktadır. Nakit akımı yöntemi yaygın kullanılmasına rağmen, bu yöntemin uygulanmasında geleceğe yönelik belirsizlik arttıkça bir dizi yetersizlik ve eksiklik ile karşılaşılmaktadır. Böyle bir ortamda, deterministik analiz amaca hizmet etmemekte ve yetersiz kalmaktadır. Belirlilik durumu; karar vericinin önceden kararla ilgili tüm parametreleri kesinlikle belirleyebildiği durumu ifade etmektedir. Risk durumunda ise; karar verici kararla ilgili parametreleri etkileyecek olası değerleri bilmektedir. Bu şekilde, karar verici herhangi bir parametreye belirli bir olasılık atayabilmektedir. Belirsizlik durumunda ise; karar verici kararını etkileyecek faktörlerin farkında olabilir ya da olmayabilir ve bu faktörlerin gerçekleşme olasılıklarını sayısal olarak belirleyebilir ya da belirleyemez.

İncelenen şirket değerleme yöntemlerinde, yöntem için gerekli tüm bilgilerin kesinlikle bilindiği varsayılmıştır. Uygulamada değerleme yönteminde girdi olarak kullanılan parametrelerin her zaman istenilen açıklık ve kesinlikte temini mümkün olmayabilir. Özellikle, satış miktarı ve neticede satış geliri kesinlikle önceden bilinen bir parametre olmayıp piyasadaki şartlara bağlı olarak değişmektedir. Değerlemede satış miktarı veya satış geliri belli bir tahmin olarak ele alınabilir. Ancak, piyasaya sunulan malların satış tahminlerinde bir belirsizlik söz konusu ise ve her tip malın içerdiği risk oranı analize katılabilirse, karar alma sürecinin geliştirilmesi ve uygun seçim yapılabilmesi mümkün olur.Belirsizlik hali, karar vericinin ek çabası ile risk durumuna dönüştürülebilir. Ancak işletmelerde çeşitli amaçla yapılan analizlerde karşılaşılan bir güçlük, sistemlerin tam matematiksel modellerinin bilinmemesi veya modellerdeki parametrelerin zamanla büyük değişiklik göstermesidir. İlave olarak, sistem davranışının ve bu davranışın gerçekleştirilmesinde dikkate alınması gereken sınırlamaların sayısal bir değerle nicelendirilmesi her zaman mümkün olmamaktadır (Kaynak, 1996). $\mathrm{Bu}$ nedenle, şirket değerlemesinde gelecekte karşılaşılması olası farklı durumları dikkate alan yaklaşımların kullanılmasında fayda görülmektedir. Bu şekilde, şirket değerine ilişkin bir değerler kümesi elde edilebilir ve şirket ile ilgilenen taraflara verecekleri karara baz oluşturacakbilgi sağlanmış olur.

Değer konusunda uzlaşılan hususlardan biri, bakış açısına ve neyin kim için değerlemesinin yapıldığına bağlı olarak farklı değerlere ulaşılmasıdır. Buradan hareketle, değerleme işi bir sonuç bulma işi yerine daha çok değerleme sürecinin tanımlanması ve analiz edilmesidir. Başka bir deyişle, değerleme işinde elde edilecek sonuçtan ziyade, değerlemede izlenen sürecin analiz edilmesi ve modellenmesi bilimsel çalışmanın konusu olmaktadır. Değerleme bir görüş, bir bakış açısıdır ve matematik olarak kesin değildir. Herhangi bir nesneye makul bir değerin biçilmesi işi, büyük ölçüde değerlemeyi yapan uzmanın bütünü görme, doğruluk ve takdir etme yeteneğinin bir fonksiyonu olmaktadır.Bu nedenle, günümüzde işletme yönetimi açısından şirket değerinin tespiti ve yönetimi uzmanlık gerektiren bir alan haline gelmiştir (Üreten ve Ercan, 2000).

Bir şirketin değerlemesi gerçekte onun değerinin ya varlıklar bazında ya da geliri bazında değerlemesidir(Bilir ve Kulal1, 2014; Cesur vd., 1999). İşletmelerde değerleme işinde geçerli, tek bir hesaplama yöntemi yoktur. Birden fazla yöntem birbiri ile karşılaştırma yapmak için kullanılmaktadır. Şirket değerlemesi ile şirket değeri hakkında bir fikir edinilebilir. Böylece şirket ile ilgili işlemlerde müzakere gücü kazanılmış olunur. Diğer taraftan, değerleme ile bulunacak sonuçların analizi ve test edilmesi ise farklı bir bakış açısı ve çalışma konusunu oluşturmaktadır.

Ayrıca bu çalışma kapsamında incelenen şirket değerleme yöntemleri, esas itibarıyla yöntem için gerekli tüm parametrelerin değerinin bilindiği varsayımına dayalıdır. Ancak işletmelerde karar alınması gereken konular esas itibarıyla sayısal olarak ifade edilemeyecek ölçüde karmaşıtır. Bu bakımdan, belirsizlik ortamında söz konusu yöntemler amaca hizmet etmeyecektir. Bu tür durumlarda, belirsizliği dikkate alan yöntemlerinve bu çerçevede gelecekte karşılaşılması olası farklı durumları dikkate alan yaklaşımların kullanılmasında fayda görülmektedir. Bu şekilde, şirket değerine ilişkin bir 
değerler kümesi elde edilebilir ve şirket ile ilgilenentaraflara verecekleri karara baz oluşturacakbilgi sağlanmış olur.Ancak bu yöntemlerin kullanılması ile hesaplanacak şirket değerinin de diğer yöntemler ile hesaplanan değerde olduğu gibi şirket ile ilgilenen taraflara belirsizlik altında bir fikir vereceği dikkate alınmalıdır.

Açıklamalar: $\mathrm{Bu}$ çalışma, yazar tarafindan Ankara Üniversitesi Sosyal Bilimler Enstitüsünde tamamlanan "İşletmelerde Şirket Değerlemesinde Yeni Bir Yaklaşım; Fuzzy Küme Teorisi" başlıklı doktora tezinden türetilmiştir. 


\section{Kaynaklar}

Akarsu, B. (1998). Felsefe terimleri sözlüğü. İstanbul: İnkilap Kitabevi Yayın Sanayi ve Tic. A.Ş.

Akgüç, Ö. (1989). Finansal yönetim. İstanbul: İstanbul Üniversitesi.

Alkan, G. İ. ve Demireli, E. (2007). Türkiye'de kullanılan bazı şirket değerleme yöntemleri ve bir uygulama. Dokuz Eylül Üniversitesi, Sosyal Bilimler Enstitüsü Dergisi, 9(2), 27-39.

Aşıkoğlu, R. ve Aşıkoğlu, M. (1998). Bilgi toplumuna geçiş sürecinde entellektüel sermayenin işletmenin piyasa değerine etkisi. Anadolu Üniversitesi, İktisadi ve İdari Bilimler Fakültesi Dergisi, 14(1-2), 567-596.

Aydın, Y. (2012). Firma değerleme yöntemleri. Klrklareli Üniversitesi, İktisadi ve İdari Bilimler Fakültesi Dergisi, 1(1), 87-110.

Bilir, H. ve Kulalı, İ. (2014). İndirgenmiş nakit akış ve göreceli değerleme yöntemlerinin karşılaştırılması. Siyaset, Ekonomi ve Yönetim Araştırmaları, 2(2), 39-55.

Bolay, S. H. (199). Felsefi doktrinler ve terimler sözlüğü. Ankara: Akçağ Yayınları.

Campbell, A., Goold, M.veMarcus, A. (1995). The value of parent company.California Management Review, 38(1), 79-80.https://doi.org/10.2307/41165822.

Cesur, A.M. (1993). Özelleştirme ve firma değerlemesi.Ankara:Özelleştirme İdaresi Başkanlığı.

Cesur, A.M., Tekindağ, F. C. ve Ergün, T. (1999). Özelleştirmede firma değerleme yöntemleri ve Türkiye'de özelleştirme çalışmaları.Uzman Gözüyle Bankacılık, 7(26), 26-31.

Cevizci, A. (1999). Felsefe sözlüğ̈̈̈. İstanbul: Paradigma Yayınc1lı.

Chiu, H. N. and ChenH. M. (1997). Theeffect of time-value of money on discretetimevaryingdemandlot-sizingmodelswithlearningandforgettingconsiderations.TheEngineering Economist, 42(3), 203-221.https://doi.org/10.1080/00 137919708903179.

Coggan, P. (1997). Evaluating EVA for markets. The Financial Times, 22-23.

Cornell, B. (1993). Corporate valuation tools for effective appraisal and decision making.New York: Irwing Professional Publishing.

Dalgeç, A. (1992). İşletmelerde firma değerinin saptanmasına yönelik yaklaşımlar.Doktora tezi, Dokuz Eylül Üniversitesi, Sosyal Bilimler Enstitüsü, İzmir.

Damodaran, A. (1994).Study guide for Damodaran on valuation; security analysis for investment and corporate finance.New York: John Wiley \& Sons, Inc.

Damodaran, A. (1996).Investment valuation; tools and techniques for determining the value of any asset. New York: John Wiley \& Sons, Inc.

Dierks, P.A. and Patel, A. (1997). What is EVA and how can it help your company. Management Accounting, 79(5), 52-58.

Doğu, M. (1996). Gelişen hisse senetleri piyasaları ve Türkiye. Ankara: SPK Yayını.

Doğukanlı, H. (1994). Temettü politikasının firma değeri üzerine etkisi: Kazanca dayalı firma değerlemesi karşısında temettüye dayalı firma değerlemesi.İktisat, Işsletme ve Finans, 9(101102), 53-64 
Donaldson, T. and Preston, L. E. (1995). The stakeholder theory of the corporation: Concepts, evidence, and implications.Academy of Management Review, 20(1), 69-70.

Ercan, M. K. ve Ban, Ü. (2005). Değere dayalı işletme finansı-Finansal yönetim. Ankara: Gazi Kitabevi.

Ercan, M .K., Öztürk, M. B. ve Demirgüneş, K. (2003). Değere dayal yönetim ve entellektüel sermaye. Ankara: Gazi Kitabevi.

Ertuğrul, M. (2008). Değer-fiyat ayrımı ve işletme değeri: Kuramsal bir bakış. Eskişehir Osmangazi Üniversitesi, IIBF Dergisi, 3(2), 143-154.

Ertuna, Ö. (1986). Finansal kurumlar. Ankara: Teori Yayınları.

French, N.S. and Ward, C.W.R. (1995). Arbitrage and valuation.Journal of Property Research, 12(1), 1-11.https://doi.org/ 10.1080/09599919508724125.

Gacar, A. (2009). Yatırımcılar Açısından Hisse Senedi Değerlemesi. Yayımlanmamış Yüksek Lisans Tezi, Dokuz Eylül Üniversitesi, Sosyal Bilimler Enstitüsü, İzmir.

Gönenli, A. (1991). İşletmelerde finansal yönetim. İstanbul: İstanbul Üniversitesi Yayını.

Guatri, L. (1994). The valuation of firms.Oxford: Blackwell Publishers.

Kaynak, O. (1996). Bulanık denetim ve endüstriyel uygulamaları.Sistem Otomasyonu, 2-8.

Kuçuradi, İ. (1998). Insan ve değerleri. Ankara: Türkiye Felsefe Kurumu.

Lalik, Ö. (1973). İşletmelerde firma değerinin muhasebe açısından incelenmesi. Doktora Tezi, Ankara İktisadi ve Ticari İlimler Akademisi, Ankara.

Masun, M. A. (2017). Firma değerlemesi yaklaşımları ve otelcilik işletmesi örneği. Marmara Üniveristesi, İktisadi ve İdari Bilimler Dergisi, 39(1), 213-222.

Mevzuat Bilgi Sistemi (1994). Özelleştirme uygulamaları hakkında kanun.http://www.mevzuat.gov.tradresinden 12.05.2019tarihindeerişilmiştir.

Milbourn, T. (1997). EVA's charm as a performance mesaure. The Financial Times, Mastering Finance-5, 5-6.

Monnery, N. (1997). Motivations to manage value. The Financial Times, Mastering Finance-5, 7-8.

Mülayim, Z. G. (1994). Tarımsal değer biçme, genel-özel-yasal. Ankara: Yetkin Basımevi.

Öztepe, E. ve Beylik, U. (2014). Sağlık kurumlarında firma değerleme: Bir özel hastane uygulaması. İşletme ve Íktisat Çalışmaları Dergisi, 2(4), 119-128.

Öztürk, H. (2009). Şirket değerlemesinin esasları: Teorik ve pratik yaklaşımlar. İstanbul: Türkmen Kitabevi.

Piper, T. R. and Fruhan, W. E. (1981). Is your stock worth its market price? İçinde Archerr, S. H. ve Hulbert, S.K.(Eds.),Readings and cases in corporate finance(ss. 20-35). New York: McGraw Hill Inc.

Pratt, S. P. (1998). Business \&real estate appraisal practices examined.Valuation Insights\&Perspectives, First Quarter, 6-7. 
Seyidoğlu, H. (1992). Ekonomik terimler ansiklopedik sözlük.Ankara: Güzem Yayınları.

Sirel, Y. (1992). Bir şirket satmak.Bankacılar, 3(10), 32-35.

Stanley, F. S. and Olson, E. M. (1996). A value based management system, Business Horizons, 39(5), 48-52.

Süel, H. (1995). Şirket değerlemesi.Iktisat, İşletme ve Finans, 10(117), 52-61.

Torries, T. F. (1998, October). NPV or IRR? Why not both? MiningEngineering, 50(10), 69-73.

Üreten, A. ve Ercan, M.K. (2000). Firma değerinin tespiti ve yönetimi. Ankara: Gazi Kitabevi.

Ward, K. and Grundy, T. (1996). The strategic management of corporate value.European Management Journal, 14(3), 476-481.https://doi.org/10.1016/0263-2373(96)00012-6.

Yazıc1, K. (1997). Özelleştirmede değerleme yöntemleri ve değerleme kriterleri.Ankara:DPT Yayını.

Young, D. (1997). Economic value added: A primer for European managers, European Management Journal, 15(4), 335-343. 


\section{Extended Abstract}

\section{Introduction}

In today's globalized economic environment, investors can easily and quicklytransfer their capital from one place to another to obtain the highest return on the capital they invest.Today, the free movement of capital, the purchase and sale of assets or shares, divisions and mergers in companies have brought the valuation work to the agenda. Corporate valuationhas been an issue in finance literature since the 1980s.In this context, the finance discipline considers the issue as determining the corporate value from the perspectiveof company shareholders and the management of the corporate value.In this study, an overview of corporate valuation is made from a theoretical viewpoint. After the introduction, the second section examines the subjective and objective dimensions of value.The third section describes in detail the various value types. In the fourth section, the reasons for and strategic importance of corporate valuation are discussed in detail. In the fifth section, valuation approaches and corporate valuation methods are examined.In the sixth section, the subject is evaluated and discussed from different perspectives.The seventh and last section concludes the article.

\section{Dimensions of Value and Value Types}

Value has two dimensions, objective and subjective. They need to be examined separately. Subjective value is determined depending on individuals and their perspectives. The objective value is the value determined in proportion to the costs and benefits of the goods and services. On the other hand, it appears that it is difficult to make a general definition of value.However, differenttypes of value developed for commercial and tax purposes are used in practice. The analysis and modeling used in the valuation process is the subject of scientific study rather than the results obtained in the valuation work. In fact, valuation is an opinion, a viewpoint, and not mathematically precise. The assignment of a reasonable value to any object, to a large extent, is a function of the expert's ability to see the whole picture, accuracy, and appreciation.

\section{ReasonsforCorporateValuation and Its Strategic Importance}

There are many reasons why a companyshould be valued. For example; sale of a company's assets, a new shareholder, mergers and acquisitions, privatization, liquidation, and mortgageare among the reasons that require valuation.In addition, managers need to provide a strategic perspective to increase share value, identify opportunities, and find ways to benefit from them. With advanced techniques such as the cash flow method and economic added value (EVA), managers can determine which company departments contribute to the company's value and which do not.Companies can also use these techniques to create new strategies or new production lines.Today, valuation is no longer an occasional task and has become a prerequisite for making resource allocation decisions in businesses. As Ercan et al. (2003) pointed out, the objective of profit maximization has now been replaced by value maximization for today's managers.

\section{Valuation Approaches and Corporate Valuation Methods}

From the perspective of finance discipline, the corporate valuation is in fact based on various approaches such as cost, income, and market. The corporate valuation uses a method consisting of a combination of one or more of these approaches. These approaches are not different from each other and complement each other. The cost approachconsiders the cost value and the market value of the company's assets, rather than the profits of the company in the future. In the revenue approach, the value corresponds to the present value of the revenues that will be provided during the economic life of the assets.There must be a functioning market for the market approach and the exchange of assets. The market approach provides a good value indicator if similar assets havemarket prices. 


\section{Evaluation and Discussion}

In the finance literature, many methods for corporate valuation have been proposed. These methods are theoretically powerful, but the main problem encountered in practice is to determine the appropriate input parameters required by each method. In determining the method to be used in the corporate valuation, the purpose of the valuation and the structure and situation of the relevant company should be taken into consideration. Therefore, the methods to be used in the valuation should be analyzed and the strengths and weaknesses of each method should not be overlooked. In the corporate valuation methods examined, it is assumed that the value of all the input parameters required for the method is known. Today, companies operate in an environment where many variables interact. Therefore, in an uncertain environment, it will not be easy to determine the value of these inputs. In such an environment, analyzes that consider uncertainty in corporate valuation may be used. In this way, a set of valuescan be obtained for the corporate value. However, it should be noted that the corporate value to be calculated with these analyzes will give the stakeholders an idea under uncertainty.

\section{Conclusion}

Any decision made by the corporate management regarding the allocation of assets changes the corporate value. Regardless of the type of decision, decisions regarding the launch of a new product, investment in research and development, and strategic cooperation affect the corporatevalue. Therefore; as underlined by Üreten and Ercan (2000), corporate valuation has become a skill that business management should specialize in establishing and maintaining a value-based management approach in businesses. In summary, there is no single calculation method generally accepted in corporate valuation. Results found in more than one method can be used for comparison. In this respect, it is possible to get an idea about the corporate value with the results obtained using different methods.Thus, negotiation power is gained in the transactions related to the company. On the other hand, the analysis and testing of results require a different viewpoint and study.In addition, the results of analyzes considering the possible different situations that the company may face in the future can provide a valuable set of corporate values that are thought to help stakeholders' decisions. 